\title{
Foregrounding and Metaphor: A Stylistic Study on Hamza Yusuf's Religious Poems
}

\author{
Suryo Ediyono \\ Faculty of Cultural Sciences, Universitas Sebelas Maret, Surakarta, Indonesia \\ Sopyan Ali \\ Harapan Bangsa Foreign Language Academy of Surakarta, Solo, Indonesia
}

\begin{abstract}
Poetry not only communicates information but also arouses the readers' feeling to a thoughtful sense and the life's perception of the author through parable objects. Poetry could be perceptually prominent if it is expressed through linguistic deviation, which further defined as "foregrounding". This article is an attempt to provide understandings from the analysis of Shaykh Hamza Yusuf's religious poems that engage both semantic and sound patterns (phonological) analyses. The semantic level of the poems dealt with metaphorical analysis as realized in several lines that observed the foregrounded words, phrase and sentences which are semantically deviant, and are classifiable into personification and depersonification. At the phonological level, the sounds patterns cover the use of certain sounds found on major lines of both poems, the distribution of similar sound patterns can produce the aesthetic effects, the common observed styles found in Hamza Yusuf's religious poems are the repetitions or anaphora, assonance, alliteration, rhythmic sounds of the beginning, in- and end rhymes, and the middle rhyme.
\end{abstract}

Index Terms—religious poetry, foregrounding, metaphor, semantic and phonological level

\section{INTRODUCTION}

Poetry as a literary work is a manifestation of the poet's thoughts, ideas, allusions, and messages either directly or indirectly conveyed to the publics. Richards (1970) in his book science and poetry suggests (1926) that 'poetry is a unique form of discourse'. In essence, poetry not only communicates information but also arouse the readers to a thoughtful sense and the life's perception of the author through parable objects, which in terms of it meaning can be differently perceived-To understand the content of a poem, a person needs to have knowledge of poetry appreciation; otherwise shall not be able to appreciate the poetry. Thus, any observer of poetry should have an understanding of poetry appreciation, and the sense of beauty of the expressed poem (poetic thoughts).

Poetic thoughts aesthetically realized through particular expressions that for common people these can be complicated to be expressed. A poet needs to balance the presumptions of both 'accuracy' and 'decency', which means poetry observer should stay focused on the accurate expression of 'poetic ideas', in addition to deeply thinks of how these expressions can be accessible to the audiences (Furman, et al., 2006, Sherry \& Schouten, 2002). This article mainly aims to answer the question on how the poet express his poetic thoughts within religious genre?, can anyone of the readers beyond the poet's 'episteme' or background knowledge to understand the whole meaning of each poetical line. Literary critics view this as an interpretive question, which depends on the fineness and clarity of style (stylistics) of the author's intuition, the ability to experience the poetic thoughts (in addition to be able to reflect back on each of those experiences). Specifically, I propose a theoretical question, as does Richards, Roman Jakobson and experts of Russian formalists view poetry as a realization of language functions.

Stylistics is a discipline associated with the language of literature in particular, despite it often-it frequently addressesed to some variety of language use, unexceptional to literature. Stylistics provides assistance for observers of language literature to take a deep look at what the author attempts to say through potentially appealing meanings of the poetical expressed language. The written language resources, i.e., figurative language such as metaphors and similes are the most respectively used in all kinds of speech and written language. In addition to the use of literary devices, the presence of metaphoric elements are one of the most widely used in any literary texts; it is even a specific 'package' that provides a greater contribution to the meaning (Black, 2006, p.231).

Stylistics provides ways of linguistic analysis on literary works. Stylistics serves as a medium between literature and linguistic studies. The linguistic elements in the language of literary work can be fully understood into its distinguishing patterns and structures; it provides ways to describe such a genre. In its historical journey, stylistics had not yet been claimed as a discipline until modern times. In terms of the methodology, stylistics concerns the linguistic analysis. The typical modern literary stylistics focuses mainly on the area of literary criticism (cf. McIntyre, 2012, Xin Li \& Shi, M., 2015), i.e., on the case of poetry, stylistics helps language observers examining the interpretative meanings as realized in phonetic phenomena (Miall, 2001, p.56). A Stylistic study of Robert Frost's Poetry by Sumera Batool et al. (2014) suggested points of view that "an interpretation of a literary work, especially poetry, is diverse for every reader of the 
texts. Interpretations should never be qualified as the only fact; there are different views and understanding that can make an interpretation of a poem accesible for every reader." Apart from differently produced interpretations about the poetical meanings, Michael Toolan (2016) in his article "Stylistic iconicity and Love's two orders of language" argued that "stylisticians majorly unaware of their difficulties, that the strong connection of the second-order description to the first-order description intermediated by the iconicity". He maintained a view that by 'the stylistic iconicity' the addressee of a poem can 'grasp the meaning without prior knowledge of the language in which it is carried' (Toolan, 2016, p.7).

Some of the text features which reflect more effects to the readers known as 'foregrounding'. Öztekin (2013) explained foregrounding as linguistic elements that concern affecting the psychological state of the readers. The analysis of foregrounded features provides us with a significant insight about the meaning patterns of poems". He (2013) further explained that "foregrounding may lead to repetitions and deviations in the poetical language". The foregrounded features according to Miall (20011, pp.66) in his paper "Sounds of contrast" involve doing analysis on the assonance or metrical effects at the phonetic level, grammatical level and semantic effects of metaphor.

This article attempts to provide understanding, descriptions and interpretation of the metaphorical and foregrounding use in Sheikh Hamza Yusuf's religious poems. Hamza Yusuf Hanson is renowned for both as an Islamic scholar and Sufi, and is an influential Moslem American from Washington, USA. He converted to Islam in 1977 at the age of 17 years and spent many years studying in Arab countries, such as Emirate United Arab Emirates, Algeria, Saudi Arabia and Mauritania. In addition, he is also the founder and leader of Zaytuna College in Berkeley. It is the first Islamic college accredited and internationally awarded as a campus that applies classical Islamic education in the Western world, which is dedicated to revive the methods of science and teachings of the Islamic tradition.

The deviation of linguistic elements attributed in literary texts is theoretically called foregrounding; it evokes readers with the analogy of a figure represented by poetical lines (Leech, 1969, p. 57). The poet creates "defamiliarization" through linguistic "dislocation" that calls readers' attention the awkwardness of the portrayed or depicted world in the literary work (Hardison, 2010). This study seeks to provide a general picture and understanding of how religious poetry is being represented through perspective of both literary and linguistic studies. It takes a stance from previous studies conducted by Sumera Batool et al. (2014), Michael Toolan (2016). The present study probes the religious poetry which expresses different kinds of positions, attitudes, and feelings directed by the poet to evoke certain meanings. The linguistic elements in the language use of a literary work can be fully understood into its distinguishing patterns and structures emphasizing on the foregrounded aspects in semantic and phonological level.

\section{THEORETICAL UNDERPINNINGS}

The beginning of the 20th century, members of the Formalist Linguistic Circle in Moscow (the Russian formalists), such as I.A Richards had a focus interest on the analysis of texts of language in relation to the manifestation of the psychological effect on the linguistic structure. Roman Jakobson left Moscow at the time of the Russian Revolution and moved to Prague, where he became a member of the Prague Structuralists Association. Both associations contribute in developing the so-called theory of 'foregrounding' (Preminger and Brogan, 1993, p.411). This view suggests that some parts of the text have more effect on the reader than others in terms of interpretation, because the portions of textual linguistically deviant or specially patterned in some cases, making these elements are psychologically salient (or 'foregrounded') by the reader.

\section{A. Foregrounding}

Foregrounding is a concept that was formerly introduced by Czech theorist Jan Mukărovsky (1964 as cited in Miall \& Kuiken, 1994, p.390) with original term aktualisace and was translated in English into foregrounding. The notion refers to the stylistic variations that can be found in literature, among those literary variations such as alliteration, rhyme (at the phonetic level), inversion and ellipsis (at the grammatical level) and metaphor and irony (at the semantic level). Furthermore, a good poetic text observation analysis can be done by examining the important foregrounded parts by author and describe the elements of analysis and interpretation that connect those parts together. Having characteristically positioned as part of a text feature, foregrounding enables the author to highlight the expressed written thoughts or feeling that can either be consciously or unconsciouly stated [...]" (Short 1997, p.36; Miall \& Kuiken, 1994). Some authors named this strategy as linking features "cohesion of foregrounding" (Leech 1969). These foregrounded features in the text violated the constructed, defined and specified rules at each level of language. Native speakers, like many second language learners acknowledge that this feature is odd, which marked by stylistics and are substantially expressive in nature. However, as firmly stated by Short (1997, pp. 37), we need to ensure that "our intuition is reasonable, and not based on personal whim". Thus, we need to analyze and describe the nature of the deviations.

Foregrounding is quite often studied in poetical texts where the elements of language (reflecting the aesthetic function) considered as the main source of the unexpected language use tool. Leech further explained that "foregrounding is a means to achieve a goal: it is the creation of an effect, a special effect which invokes the analogy of a figure (Leech 1969, p. 58-61). Pragmatic dimension that discusses it for it "is much more than a neutral objective description over the world" and intended to explain the social situation" (cf. Fowler 1986, p.9). Deviation, as clearly defined by Short (1996, pp.11) is a "linguistic phenomenon which reflects a significant psychological effect on readers 
(and hearers) of a poem". Similarly, a literary text would be perceptually prominent if it is expressed linguistic deviant. This psychological effect according to Short (1996) is so called "foregrounding". The "foregrounded "element in any given text is a pivotal part to fully understand the conveyed message (s).

Through foregrounding, everything the poet wants to tell with the poetry is about his personal, more importantly "real" experiences and observations, through identical movements and insightful words that go hand in hand (Leech, 1969, p.65) whether to reflect spiritual and physical experiences of him. Shaykh Hamza Yusuf, the poet whose poems are going to be analyzed in this study aroused the impression of his audiences (both listeners and readers) by giving certain emphasizes on the foregrounded aspects in semantic and phonological level. These foregroundings enhance reliability of the poet and his facts related the creaed poem. In this hopefully simple study, we will address our stylistic interpretation to the two poems of a well-known American Islamic Scholar, Shaykh Hamza Yusuf Hanson entitled "A Tree Knelt in Praise" and "Spring's Gift" through comparative metaphor, sound patterns (parallelism), and semantic deviations.

\section{B. Metaphors}

Metaphors are conceptually and traditionally acknowledged as the language use that functions to compare between the target (a-tem) and the base (b-term). Not surprisingly metaphor as many linguists would call as is a simple featurematching process, but some may be defined it as 'a process of mapping between two different conceptual domains', it is 'basic schemes through which people conceptualize their experience and their external world'. In general, people use metaphor to express many things in their daily life interactions. Metaphors are not often found in poetical thoughts (imagination world), the complexity of real world problems is quite often solved by metaphors and analogies, the aim of metaphorical expression drives the point of perceptions between attitudes and mind (cf. Arora and Arora, 2015, p. xvi, case for metaphors in Socio-Engineering). At least, none of the available theories truly satisfied the explanation on the concept of metaphor, since it engages the understanding of language in relationship with the human mind (Paprotté and Dirven, 1985; Lakoff and Johson; Mey, 1994 cited in Black, 2006, p.102).

\section{ANALYSIS AND DISCUSSION}

\section{A. Personification}

Personification is defined as using comparative similes and metaphors to give living qualities to non-living objects or ideas, which is part of the figurative language.

A tree who like us loved to pray (3)
In adoration every day (4)

(“A Tree Knelt in Praise”)

The compared element of an adjective 'like' and the noun 'adoration' express the human feelings, but both semantically deviant from the nature of a tree. The pragmatic inference for the denoted thing implies that 'a tree whose existence generated benefits, the presence protects anything under it from the scorching heat and for the produced fruits and the woods benefiting human needs of life'. The distinguishing componential meanings of "Agree who like us loved to pray" and "in adoration everyday", the phrase 'happy' and 'adoration' supposed to be juxtaposed with the human being's natures (semantic deviation). Though, it is somewhat relevant to animals which instinctively feel pleased, while in adoration that closes in meaning to the word 'submission' (for fear and feel threatened, etc.) where both imply the same living entities that can interact towards one another. The personification in above passage imply certain meaningful expression that the author needs to covey to the publics in which the 'tree' is a figurative expression of the presupposition for 'the Prophet (Muhammad, the last prophet of Islam)' as a subject figure who provides a lot of benefits for mankind, and pleased with ' $\boldsymbol{u s}$ ' (the followers) who obey the God's command (obeying His command through righteous deeds). The foregrounded aspects of such sentence can perhaps be fully understood by readers of the same episteme (background knowledge) in order to properly use the mental knowledge known as inference. To an extent, the inference can only be made by readers who know the indirectly described figure behind the poetical lines.

The other similar data of personification in Shaykh Hamza Yusuf's poem is on below passage.

It taught us all to clearly see (17)

("A Tree Knelt in Praise")

The compared elements of the pronoun it (refers to the tree), personifically gives 'shade' and 'teach'. The pragmatic inference for the denoted act of 'taught' is metaphorical to the nature of shade giver, assuming that a person who is under the tree shall be protected from the scorching sun or heavy rain; it enables a person to feel comfortable and is able to clearly look around. The differentiator of such meaning of a sentence structure "it taught us to clearly see", in essence, the reference of tree is an entity that cannot overshadow the person (actively) instead the person who shaded themselves by coming across to and situated themselves under the tree. Obviously here, the semantic deviant in the expression of 'teaching', just being able to teach is an act that can 'only' be done by human beings. Therefore, the word element in the semantic meaning for a tree is, therefore, unable to teach, the verbal expression of 'teaching' is beyond the collocation of the tree and its attributive elements. By the metaphoric expression or simile reflected from the use of personification, the message directs the public readers contemplating to the role of Muhammad as a prophet and teacher 
who literally comfort his followers (metaphorically expressed with 'shade') that thereof someone enlightened with the light of 'science', allowing them to see clearly to the truth and falsehood.

I envy the sand that met his feet (1)

(Spring's Gift-)

The compared element is the 'sand that met his feet' presupposed 'the prophet who was sent by God in a desert place, Arab'. The pragmatic inference for this case is that the significance for such utterance, the meeting was testified by the God's creation (sand) with the inferred human figure (Muhammad). The differentiator components of meaning for 'the meeting sand' implies the will of such person to step on the sand, so there was a meeting between his (Muhammad) feet with the sand, conversely sand did not meet the person's feet. The use of personification to express jealousy of the author on the meeting sand, it was the people who lived in the time of the prophet Muhammad, and became friends of him. Thus, the sand that met his feet semantically deviant, since the action of meeting can only be paired to the living and self-moving creation or being.

\section{B. Depersonification}

Depersonification is a kind of figurative language that featured humans as animals, natural objects, or other inanimate objects. It is the opposite of personification. The below passage provides examples of depersonification in Shaykh Hamza's poem.

With his, whose face did shine so bright (9)

(Spring's Gift)

The compared element is the human body part, 'the face' (implied Muhammad's) 'did shine so bright'. The equalizer components of meaning for the 'shine or shining' closes in meaning to the word 'illuminating', which is the absolute nature possessed by 'light', and is a source of energy providers that can benefit all his surroundings. The writer evokes a sense that the nature of the told person has a quality of shining face, because of his obedient to the God, performing prayers so often. Contextually, in Islamic belief, someone who often performs prayers, his face turns brightening or clean (because of taking ritual ablution before the prayers begun). Therefore, the describe figure was 'Muhammad shoes face did shine so bright' as oppose to the darkness. Conversely, the 'darkness' in opposite to 'bright' or lightness is conceptually defined in negative term as a quality which commonly associated other distinguishing concepts such as 'ignorance', 'adversity, and' contempt'. The inference of such word meaning is to denote Muhammad as a human being whose body and soul are comparable with something that generates physical light such as the sun, lamps or lanterns. But the dimension of light which the author wishes his audiences to reflect was the light in spiritual dimension, in which the Prophet Muhammad is the source of light 'science' whose teaching and life guidance removes the humans' ignorance. Here, we would say for the foregrounded aspect of 'the face did shine so bright' and many more found in the passages is a highly motivated deviation (cf.Leech and Short, 2007, p.48), especially the way the author views the figure in his poems (with a sense of highly valued human or perhaps tend to be exaggerated).

\section{For he was born to grace our Spring (46)}

With lilies, flowers, life's rebirth (47)

(Spring's Gift)

The compared elements found in the sentence 'he was born to grace our Spring, lilies and other flowers'. The equalizer component of meaning for the word 'birth' is the presence of an important person on earth, and was a mark for a new dawn bright. The birth of the implied figure was Muhammad, the one who intermediates man with the God to teach humans life nobility. The author figuratively used the parable of Spring as a peaceful concept of word, like the green was the mark for the Spring, and is accordingly the highest spectrum of colors (Hamza Yusuf's speech before reciting the poem Spring's Gift). The historical context for such account is the Prophet Muhammad's birth was coincided with the arrival of spring, and during his lifetime he chose the color of green as his favorite color. Conceptually, the 'green' as a marker for the 'Spring' arrival, for it is also correlated with 'photosynthesis' symbolizing the process of natural life (plants, extensively the world creatures). In addition, the color of green is a primary color that must be seen by a person who gets up early in the morning and then opens the window at the first time (the green color of the plants), all of which relate the core marks of the beginning of a better life, the foregrounded phrase here is on 'life's rebirth'. While the implicit metaphorical meanings displayed by 'lilies and some mentioned flowers' can be specifically defined, to borrow the concept of Christianity, that the lilies is associated with a sense of nature and attitude of obedience (devotion). In the metaphor of the Christianity, the lily is a symbol of obedience, majesty and holiness, "lily meaning and Symbolism".

Or he was sent by God to men (37)

To hone their spirits' acumen (38)

(Spring's Gift)

The compared elements 'to hone their spirits' acumen' can be pragmatically inferred as "sharpening spiritual acuity" "establishing spirituality". The equalizer components of meaning is 'to set efforts for a change', the parable of the word 'to hone' is 'to sharpen' i.e., a knives or sword, sharpening the blunt part (of blade), whereas in humans, sharpening is metaphorical as upholding the truth to the soul / spirituality. The distinguishing component of meaning 'to hone their spirits' acumen' is that between the object and the soul are materially different. In addition to being sharper in sprit's acumen' enables a person to cut or peel the reality of an object. 'To hone spirit's acumen' semantically deviant, because 
the word 'honing' is generally collocated with the parts of an object that is used for cutting or peeling the other objects (of material).

\section{Poetic Sound Patterns}

Aspects of sound in poetry are quite substantial to both the writers and the enthusiast readers or listeners; sounds significantly serve to provide melodious poetry. Likewise, the selection and placement of words within a poem are much more relied on the value of the sounds; hence the power of the words generated responsive thoughts to the readers or listeners. According Wellek and Warren (1977, pp.158), "every work of literary art is, first of all, a series of sounds out of which arises the meaning". Furthermore, Pradopo $(2004$, p.1) elaborated that the sound style covers the use of certain sounds to achieve certain levels of effect, namely the aesthetic effect, among the common observed styles are the repetitions, assonance, alliteration sounds along with rhythmical divisions such as beginning rhyme, the in- and end rhymes, and the last is the middle rhyme.

\section{Assonance and Alliteration}

In poetry often encountered rhyme that occurs in a single line. The similarities can be realized in consonant sounds or 'alliteration' and the vocal so called 'assonance'.

A tree who gave our scholars shade (9)

A tree whose worth cannot be told (13)

Or ever lent or bought with gold (14)

A Tree Knelt in Praise)

I'm jealous of honey he tasted sweet (2)

It's pride that blinds us from the sight (39)

Muhammad has God on his side (44)

(Spring's Gift)

On the line meter (9) appeared as alliteration, s-s $\rightarrow$ scholars, shade.

On the line meter (13) appeared as assonance, o-o-o $\rightarrow$ worth - cannot - told.

On the line meter (14) appeared as alliteration, $\mathrm{t}-\mathrm{t} \rightarrow$ lent - bought

On the line meter (2) appeared as assonance, $\mathrm{i}-\mathrm{i}-\mathrm{i} \rightarrow$ honey - he - sweet.

On the line meter (39) appeared as alliteration, ai-ai-ai $\rightarrow$ pride - blinds -sight.

On the line meter (44) appeared as alliteration, d-d-d $\rightarrow$

Muhammad, God, side \& h-h $\rightarrow$ his, has.

On the line meter (44) appeared as assonance, a-a $\rightarrow$ Muhammad, God.

The vocal and consonant of sounds repetition in above passage produced rhythmical sounds, and sonority that serve to stiffen the words but in melodious way to evoke certain senses created by the author. Apart from the unique use of both consonant and vocal, do the sounds of words really convey meaning?, of course any poetical sound convey meaning, certainly "the specific phonemes" as emphasized by Miall $(2011$, p.56) "encode innate meaning, whether visual, spatial or kinesthetic". In the poem of Spring's Gift' on the line meter 44, the author establishes alliteration that can be combined with assonance within a single line meter. This creates influential and thoughtful sense which further produces a more melodious atmosphere. Thus, the poetic effects on the above passage can electively affect the listeners or readers' feeling on the similar symbolic sounds.

\section{Rhyme}

Sound repetition generally realized in poetry, including the previously described, the assonance and alliteration. Anywhere the rhyme situated, whether in the beginning, middle and end pattern reflect aesthetic / beauty language in accordance with the repeated sounds: "first, the repetitions are entirely a matter of sound [.....] make enough impression on the ear to significant in the sound pattern of the poem" (Perrine, 1984, p.182), the mechanical repetitions often called parallelism, which according to Jacobson (1960, pp.423) "is an apportionment of invariants and variables". That is why, the sound of poetry often created to be expressive (Miall, 2011, p.56). Furthermore, the repeated sounds function as an evaluation and the main sustainer of the symbolic meaning which closely related to taste or sense, as described Perrine (1984, pp.177) "the poet, unlike the man roommates uses language to convey only information, chooses his words for sound as well as for meaning and he uses the sound as a means of reinforcing his meaning".

In common poetry, the most commonly used of poetical lines are:

\section{Anaphora}

Anaphora is a kind of linguistic units repetition which can be found in the form of words or phrases appeared in each first line or the successive sentence (Sumarlam, 2013, p.56), it significantly function to affirm, emphasize and demonstrate the importance and gives the intensity of the utterances or sentences.

A tree who gave our scholars shade (9)

And never asked that it be paid (10)

A tree whose needles never hurt (11)

(A Tree Knelt in Praise)

With those who prayed, and fasted too (15)

Simply because he told them to (16)

With truth and kindness, charity (17) 
To hear him say there is one God (36)

Or he was sent by God to men (37)

To hone their spirits' acumen (38)

(Spring's Gift)

The foregrounded aspects shown by anaphora in each first line of the second poem of Shaykh Hamza Yusuf above reflect interests of the author to the readers. By foregrounding, the poet intentionally leads the reader's attention to a certain point. In showing the identical elements of poetry, the author wishes the readers to capture the importance of the poetic feature of language that he observed. Those identical elements can be either similar or contrastive forms with the successive line afterword, i.e., the identical feature as realized in phrasal repetition "a tree who.....and a tree whose..... "the use of the beginning line with identical verb bases "to hear..... and to hone.....". In such a case, the author expects the audiences to infer from the passage. It significantly implies a meaning that Muhammad was neither a God nor the one who would claim himself so. But he was just the messenger of the God to invite people declaring a fact that 'there is only one God' in the universe. In addition, the poem "The Spring's Gift" reflects the rhymical lines that observed less anaphoric structure in cooperation with "A Tree Knelt in Praise" poem.

\section{Internal or Middle Rhyme}

Middle rhyme line is the symmetrical sound in the middle between the two lines of a poetry, Perrine (1984, p.180) suggested a view that middle rhyme occurs ' when one or both riming words are within the line'.

A tree whose worth cannot be told (13)

Or ever lent or bought with gold (14)

A tree who showed us all its height (15)

(A Tree Knelt in Praise)

Of a sun whose light could not compete (8)

With his, whose face did shine so bright (9)

(Spring's Gift)

Middle rhyme line of the same occurring sounds on both poems established harmonious atmosphere between the center sounds. Middle rhyme evokes the listeners' feelings so that it can spur the desired poetic atmosphere. The above center rhyme realized not only in words level of form but also the syllables. In comparing both poems, 'A Tree knelt in Praise' poem consist more middle rhyme rather than the Spring's Gift.

\section{End Rhyme}

The end rhyme is considered to be the most rhyme pattern used by poets. It is similar sounds positioned in the end of a line, as described by Perrine (1984, p.180)"when both riming words are at the ends of lines".

$\begin{array}{ll}\text { A tree who humbly knelt in praise (5) } & \rightarrow \text { a } \\ \text { To God and never chose to raise (6) } & \rightarrow \text { a } \\ \text { A tree who showed us all its height (15) } & \rightarrow \text { a } \\ \text { With God by bowing with delight (16) } & \rightarrow \text { a } \\ \text { (A Tree Knelt in Praise) } & \\ \text { I envy sightless trees that gazed (11) } & \rightarrow \text { a } \\ \text { Upon his form completely dazed (12) } & \rightarrow \text { a } \\ \text { Not knowing if the sun had risen (13) } & \rightarrow \text { a } \\ \text { But felt themselves in unison (14) } & \rightarrow \text { a }\end{array}$

(Spring's Gift)

The end rhyme in above both poems reflects alignment of the final sounds such as praise-raise and height-delight etc. Through consistent rhythmical end, the poet intentionally evokes the readers to a deep sense of his spiritual experience by making those end rhymes unfamiliar in the listeners' ears. The foregrounded aspect as shown in the end rhyme that prolonged by the author upon reading these alignment sections with rhythmical sounds reflects an aesthetic sense of both poems.

\section{CONCLUSION}

As illustrated from several foregrounded aspects found in both semantic metaphor and stylistic sound patterns analyses on the two poems, enable us to derive conclusion that at the semantic level of the poems dealt with metaphorical analysis realized in figurative language use of personification and depersonification. I.e., a sentence "it taught us to clearly see" line 17 in the poem "A Tree Knelt in Praise" shows the use of personification. The distinguishing meaning between the objects exemplified from the data such as a tree, should not be properly designated to human nature. The semantic deviant shown in the expression of 'teaching', since being able to teach is an act that can 'only' be done by human beings (and more described in the findings). Hence, it is justifiable that people of beyond specific episteme (background knowledge) with the author and the community may not be able to fully grasp the complete meanings of the poems. Again, by this finding, the claim that has been made by Toolan (2016, pp. 7) in which "readers can grasp the meaning without prior knowledge of the language in which it is carried" is semantically contradictable. At the phonological level, the sounds patterns cover the use of certain sounds found on major lines of both poems, the distribution of similar sound patterns can produce the aesthetic effects, the common observed styles 
found in Hamza Yusuf's religious poems are the repetitions or anaphora, assonance, alliteration, rhythmic sounds of the beginning, in- and end rhymes, and the middle rhyme.

\section{REFERENCES}

[1] Arora, N. and Arora, V.K. (2015). Life-Long Education for the Global Workforce in the Socio-Engineering Age. Pertanika Journal of Social Sciences and Humanities, 23 (1): iii - xxvi (2015). http://www.pertanika.upm.edu.my/.

[2] Batool, S., Bari Khan, A., Iqbal, A., Khurram A., Rafiq, R.M.H. (2014). "Stylistic Analysis of Robert Frost's Poem: “The Road Not Taken". Journal of ELT and Applied Linguistics (JELTAL), 2 (4), 2014-12-05. http://www.jeltal.com/yahoo_site_admin/assets/docs/6.338102825.pdf.

[3] Black, Elizabeth. (2006). Pragmatic Stylistics. Edinburgh: Edinburgh University Press Ltd

[4] Furman, R., Lietz, C. and Langer, C. L. (2006.). "The Research Poem in International Social Work: Innovations Qualitative Methodology". International Journal of Qualitative Methods, 5 (3) September 2006. https://sites.ualberta.ca/ iiqm/backissues/5_3/PDF/furman.pdf.

[5] Fowler, R. (1986). Linguistic Criticism. Oxford: Oxford University Press.

[6] Hamza Yusuf. (2017). Zaytuna College/About, "Why Zaytuna College?", http://www.zaytunacollege.org/about (accessed 23/11/2018).

[7] Hardison, Karen P.L. (2010). "What is "foregrounding," which is a major stylistic device amongst creative writers?". Guide to Literary Terms. https://www.enotes.com/homework-help/foregrounding-major-stylistic-device-amongst-191877. accessed 19/11/2018).

[8] Investigative Project. (2011). "Hamza Yusuf. - Co-Founder, Zaytuna College. "An IPT Investigative Report”, (Apr 18, 2011). www.investigativeproject.org. (accessed 17/11/2018).

[9] Jacobson, R. (1960). Linguistics and poetics. In T.A. Sebeok, ed., Style in language. Cambridge, Mass.: MIT Press, pp. 350377

[10] Leech, G.N., Short, M.H. (2007). Style in Fiction, ( $2^{\text {nd }}$ Eds). Longman, London

[11] Leech, Geoffrey. (1969). A linguistic guide to English Poetry. London: Longman

[12] McIntyre, Dan. (2015). "Linguistics and literature: stylistics as a tool for the literary critic". SRC Working Papers 1: 1-11. http://symbiosiscollege.edu.in/wp-content/uploads/2015/03/ee-cummings.pdf. (accessed 23/11/2018).

[13] Miall, D.S \& Kuiken, D. (1994).: Foregrounding, Defamiliarization, and affect: Response to Literary Stories. Journal of Poetics, Elsevier. 22 (1994) 389-407, 1994. http://marul.ffst.hr/ bwillems/fymob/foregrounding.pdf. (accessed 20/11/2018).

[14] Sikora, S., Kuiken, D., \& Miall, D. S. (2011, March 21). Expressive Reading: APhenomenological Study of Readers' Experience of Coleridge's The Rime of the Ancient Mariner. Psychology of Aesthetics, Creativity, and the Arts. Advance online publication. doi:10.1037/a0021999.

[15] Miller, G.A. (1979). "Images and Models, Similes and Metaphors". In Ortony, A. (Ed.), Metaphor and Thought. New York: Cambridge University Press

[16] Öztekin, Őzge. (2013). "Foregrounding in Turkish poetry as a stylistic expression”. Procedia - Social and Behavioral Sciences, 70, (2013), 110 - 11. (accessed 20/11/2018).

[17] Perrine, Laurence. (1984). The Element of Poetry. New York: Harcourt Brace Jovanovic, Inc. Wasington D. C

[18] Preminger, A., \& Brogan, T.V. (1993). The New Princeton Encyclopedia of Poetry and Poetics. Princeton, New Jersey: Princeton University Press

[19] Richards, I. A. (1970). Poetries and Sciences: A Reissue of Science and Poetry (1926, 1935) with Commentary. London: Rutledge \& Kegan Paul

[20] Short, M. (1997). Exploring the Language of Poems, Plays and Prose. London: Longman

[21] Sherry, J. \& Schouten, J.W. (2002). A Role for Poetry in Consumer Research. Journal of Consumer Research, Inc. (29), September 2002. DOI: 0093-5301/2003/2902-0005\$10.00. https://www3.nd.edu/. (accessed 15/11/2018).

[22] Simpson, P. (2004). Stylistics - A resource book for students. London: Rutledge

[23] Sumarlam. (2013). Teori dan Praktik Analisis Wacana [Discourse Analysis: Theory and Practice, Trans.]. Surakarta: Penerbit Buku Katta

[24] Toolan, Michael. (2016). "Stylistic iconicity and Love's two orders of language". Journal of Language Sciences, Elsevier. 2016. http://dx.doi.org/10.1016/j.langsci.2016.09.016.

[25] Walek, R. and Warren, A. (1977). Theory of Literature. New York: Hartcourt, Brace

[26] Xin Li \& Mengchen Shi. (2015). "A Stylistic Study on the Linguistic Deviations in E. E. Cummings' Poetry. Pan- Pacific Association of Applied Linguistics, 19 (2), 2015, pp. 23-54. http://files.eric.ed.gov/fulltext/EJ1092438.pdf.

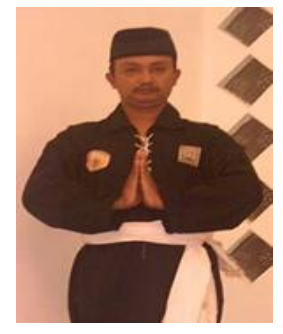

Suryo Ediyono, M.Hum., interested in the field of philosophy since he received a degree of Philosophy at the University of Gadjah Mada, which he completed in 1990. He went back to school for a master degree program Philosophy of Science, Gadjah Mada University, Central Java, Indonesia and graduated in 1998. He continued to hone his knowledge up to the doctoral level. With a dissertation titled Pencak Silat Martial Formation of Self-concept Java Man (Study Martial Pencak Brotherhood of Setia Hati Terate), he earned a doctorate in Philosophy from the University of Gadjah Mada in 2005. The studies were focused on indigenous commuting. Continuing his dissertation, he several times researching on martial arts, ranging from philosophy and function as the formation of self-concept in the Java community. He is currently a lecturer in both post and undergraduate program of Universitas Sebelas Maret, Surakarta, Central Java, Indonesia. 


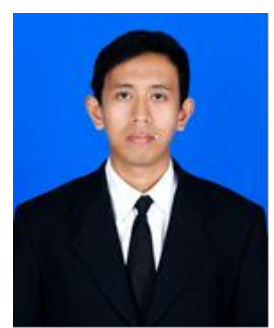

Sopyan Ali, S.S., M.Li. Holds a Master Degree in Linguistics, and currently teaches at the Foreign Language Academy Harapan Bangsa of Surakarta, Indonesia. 